\title{
Composted Biosolids Incorporation Improves Turfgrass Establishment on Disturbed Urban Soil and Reduces Leaf Rust Severity
}

\author{
Cerinda Loschinkohl and Michael J. Boehm ${ }^{1}$ \\ Department of Plant Pathology, The Ohio State University, Columbus, \\ OH 43210-1087
}

Additional index words. composted sewage sludge, Kentucky bluegrass, Poa pratensis, perennial ryegrass, Lolium perenne, subsoil, leaf rust, Puccinia sp.

\begin{abstract}
The effects of incorporation of compost to a disturbed urban soil on turfgrass establishment, growth, and rust severity were assessed in a replicated field study. A blend of two locally available composted biosolids (sewage sludge) was incorporated into a nutrient-deficient subsoil at a rate of $130 \mathrm{~m}^{3} \cdot \mathrm{ha}^{-1}$, adding $\mathrm{NO}_{3}-\mathrm{N}, \mathrm{P}$, and $\mathrm{K}$ at 126, 546, and $182 \mathrm{~kg} \cdot \mathrm{ha}^{-1}$, respectively, to each compost-amended plot. Kentucky bluegrass (Poa pratensis L.), perennial ryegrass (Lolium perenne $\mathrm{L}$.), and a mixture of these two species were seeded into both compost-amended and nonamended plots and observed for 1 year. Turfgrass establishment estimated from visual assessments of percentage cover and growth measured by clipping yields were significantly $(P<0.05)$ enhanced by the incorporation of the composted biosolids. These effects were first observed and most pronounced on plots seeded with perennial ryegrass and were apparent for the duration of the study. The severity of leaf rust caused by Puccinia sp. was significantly $(P<0.05)$ less on perennial ryegrass seeded on the compost-amended plots. This study demonstrates the feasibility and potential benefits of amending disturbed urban soils with composted biosolids to enhance turfgrass establishment and is the first report of the suppression of a foliar turfgrass disease through the incorporation of compost into soil.
\end{abstract}

Establishing lawns following construction of new homes is frequently difficult. During construction the topsoil often is removed or covered with basement fill, construction debris is buried, and heavy equipment compacts the remaining subsoil. New homeowners face the challenge of growing a lawn on these disturbed soils. Early in the 20th century, homeowners were advised to grow cover crops for one or more seasons to improve soil tilth and fertility before seeding turfgrass (Barron, 1923). Current recommendations based on agronomic research include amending the soil prior to seeding with organic materials (Pound and Street, 1991). Manures and other organic agricultural wastes sometimes are used for this purpose in field soils (Larney and Janzen, 1996), but transportation costs and availability of these materials limit their use in urban

\footnotetext{
Received for publication 25 Aug. 2000. Accepted for publication $16 \mathrm{Jan}$. 2001. Support for this project was provided by the USDA North Central IPM Grants Program and the Ohio Turfgrass Foundation. Salaries and research support provided by State and Federal funds appropriated to the Ohio Agricultural Research and Development Center, The Ohio State Univ. We thank H.A.J. Hoitink, L.V. Madden, S.T. Nameth, L. Rhodes, R.M. Riedel, and D.J. Shetlar for their assistance in the preparation of this manuscript. The cost of publishing this paper was defrayed in part by the payment of page charges. Under postal regulations, this paper therefore must be hereby marked advertisement solely to indicate this fact.

1'Assistant Professor. Boehm.1@osu.edu
}

sand-based putting green rootzone mix (Markham, 1998). Composts have also been used to replenish or even substitute for soil in sod production (Logsden, 1991; Murray, 1982). Topdressings consisting of composted biosolids have been used to supplement or replace urea-based fertilizers on putting greens and fairways (Eguiza et al., 1991; Garling and Boehm, 2001).

Composts also have been shown to reduce the severity of both root and foliar diseases of turf. Thurn (1993) in a field study and Craft and Nelson (1996) in a laboratory bioassay documented the suppression of Pythium root rot of creeping bentgrass seeded into composted biosolids-amended, sand-based rootzone mixes. There are numerous reports of compost topdressings reducing the severity of dollar spot caused by Sclerotinia homoeocarpa Bennett (Boulter et al., 1999; Garling, 2000; Nelson and Craft, 1992a), brown patch caused by Rhizoctonia solani Kühn (Nelson and Craft, 1991a), Typhula blight caused by Typhula sp. (Nelson and Craft, 1992b), and red thread caused by Laetisaria fusiformis McAlpine (Nelson and Craft, 1991b).

There is little information, however, in either the scientific or the popular literature on the use of composts for the establishment of lawns on disturbed urban soils and no previous reports on the suppression of a foliar turf disease, such as leaf rust, through the incorporation of compost to the soil. The objectives of this research were to evaluate the effects of the incorporation of composted biosolids (sewage sludge) into a nutrient-deficient, structureless subsoil typical of new housing developments on the establishment of Kentucky bluegrass and perennial ryegrass and on the development of leaf rust caused by Puccinia species. increasingly composted today and used as soil conditioners.

Incorporation of composted urban wastes into soil reduces the bulk density and increases the moisture holding capacity of amended soils (Darmody et al., 1983; Hornick and Parr, 1987), improves aggregate stability and cation exchange capacity (Aggelides and Londra, 1999), and may also increase the depth of the Ap horizon (Darmody et al., 1983). The effects of various composted materials on soil fertility and plant nutrition have been documented extensively (Darmody et al., 1983; O'Keefe et al., 1986; Pascual et al., 1997; Sikora and Yakovchenko, 1996). Composts also have been shown to reduce the incidence and severity of diseases caused by soilborne plant pathogens, such as Pythium root rot and damping off of ornamental and nursery crops (Hoitink and Boehm, 1999), Fusarium wilt of flax (Serra-Wittling et al., 1996), and Phytophthora crown rot of citrus and avocado (Lumsden et al., 1983).

Research on turfgrass also has demonstrated beneficial effects of compost amendments and topdressings. Most of this research, however, was conducted on golf course turf or was based on greenhouse or laboratory studies using sand or topsoil. For example, establishment rates and color of creeping bentgrass (Agrostis palustris Huds.) were enhanced by the incorporation of composted biosolids to a

\section{Materials and Methods}

Field plot. A $390-\mathrm{m}^{2}$ field plot was established at The Ohio State Univ. Ohio Turfgrass Foundation Research and Education Facility in Columbus in July 1998. To simulate typical construction disturbance, existing topsoil was removed to a depth of $20 \mathrm{~cm}$ and replaced with a nutrient-deficient subsoil. Three blocks, each consisting of nine $3 \times 3-\mathrm{m}$ plots separated by 0.6-m alleys, were delineated. A $1.3-\mathrm{cm}$ layer of compost $\left(130 \mathrm{~m}^{3} \cdot \mathrm{ha}^{-1}\right)$ was incorporated to a depth of $10-15 \mathrm{~cm}$ on one randomly assigned half of each plot. A mixture $(1: 1 ; \mathrm{v} / \mathrm{v})$ of two different composted biosolids was used. One source $\left(\mathrm{ComTil}^{\mathrm{TM}}\right)$ was obtained from the city of Columbus, Ohio, where it was prepared from sewage sludge mixed with wood chips by the static aerated pile method (Finstein et al., 1983). The other compost (TechnaGro ${ }^{\mathrm{TM}}$ ), received from the city of Akron, Ohio, was prepared from sewage sludge mixed with tree trimmings in an in-vessel system (Kuter et al., 1985).

The compost mixture added $\mathrm{NO}_{3}-\mathrm{N}, \mathrm{P}$, and $\mathrm{K}$ at 126,546 , and $182 \mathrm{~kg} \cdot \mathrm{ha}^{-1}$, respectively, to each compost-amended plot. Tables 1 and 2 list the nutrient properties and heavy metal content of the subsoil and the composted biosolids used in this study. Total $\mathrm{N}$ was 
Table 1. Properties of the subsoil and the composted biosolids used in this study and the loading rate for each nutrient supplied by the incorporation of $130 \mathrm{~m}^{3} \cdot \mathrm{ha}^{-1}$ composted biosolids into the subsoil.

\begin{tabular}{|c|c|c|c|}
\hline Property & Subsoil & $\begin{array}{l}\text { Composted } \\
\text { biosolids }\end{array}$ & $\begin{array}{c}\text { Nutrient } \\
\text { loading rate }\end{array}$ \\
\hline $\mathrm{pH}$ & 8 & 5.4 & \\
\hline Total $\mathrm{N}^{\mathrm{z}}$ & 800 & 27,300 & 1,014 \\
\hline $\mathrm{NO}_{3}^{-}-\mathrm{N}$ & $4^{y}$ & $3,400^{x}$ & 126 \\
\hline $\mathrm{P}$ & $2^{w}$ & $14,700^{\mathrm{v}}$ & 546 \\
\hline K & $51^{\mathrm{u}}$ & $4,900^{\mathrm{v}}$ & 182 \\
\hline $\mathrm{Ca}$ & $3,490^{\mathrm{u}}$ & $33,700^{v}$ & 1,252 \\
\hline $\mathrm{Mg}$ & $199^{v}$ & $6,700^{v}$ & 249 \\
\hline $\mathrm{Fe}$ & Not tested & $16,100^{v}$ & 598 \\
\hline $\mathrm{Mn}$ & Not tested & $1,000^{\mathrm{v}}$ & 37 \\
\hline B & Not tested & $41^{\mathrm{v}}$ & 2 \\
\hline $\mathrm{Zn}^{\mathrm{u}}$ & 82 & 1,400 & 4 \\
\hline $\mathrm{Cu}^{\mathrm{u}}$ & 25 & 214 & 8 \\
\hline $\mathrm{Mo}^{\mathrm{u}}$ & 8 & 17 & $<1$ \\
\hline
\end{tabular}

${ }^{2}$ Determined by the Dumas (combustion) method.

y Determined by the electrode method.

${ }^{x}$ Determined by the saturated paste method.

wDetermined by the Bray and Kurtz P-1 method.

${ }^{\vee}$ Determined by the neutral ammonium acetate after extraction procedure.

"Determined by the inductively coupled plasma (ICP) method after acid digestion.

Table 2. Concentrations of heavy metals in the composted biosolids and the subsoil used in this research relative to average background concentrations in Ohio soils and maximum EPA allowable levels.

\begin{tabular}{|c|c|c|c|c|}
\hline Element $^{z}$ & Subsoil & $\begin{array}{c}\text { Composted } \\
\text { biosolids }\end{array}$ & $\begin{array}{l}\text { Avg background } \\
\text { in Ohio soils }\end{array}$ & $\begin{array}{l}\text { Maximum EPA } \\
\text { allowable level }^{y}\end{array}$ \\
\hline & \multicolumn{4}{|c|}{$-\mathrm{mg} \cdot \mathrm{kg}^{-1}$} \\
\hline $\mathrm{Se}$ & $<1$ & 1 & $<1$ & 100 \\
\hline $\mathrm{Zn}$ & 82 & 1400 & 93 & 7500 \\
\hline $\mathrm{Cu}$ & 25 & 214 & 24 & 4300 \\
\hline $\mathrm{Cd}$ & $<1$ & 2 & $<1$ & 85 \\
\hline $\mathrm{Ni}$ & 26 & 152 & 27 & 420 \\
\hline As & 19 & 25 & 30 & 75 \\
\hline $\mathrm{Hg}$ & $<1$ & $<3$ & $<1$ & 57 \\
\hline Mo & 8 & 17 & 153 & 75 \\
\hline $\mathrm{Pb}$ & 12 & 69 & 24 & 840 \\
\hline $\mathrm{Cr}$ & 15 & 167 & 28 & --- \\
\hline
\end{tabular}

${ }^{2}$ Determined by microwave-assisted acid digestion.

yU.S. Environmental Protection Agency, 1997.

determined by the Dumas (combustion) method (Cunniff, 1995). Soil and compost $\mathrm{NO}_{3}-\mathrm{N}$ was determined by the electrode and saturated paste methods, respectively (Gelderman and Beegle, 1998). Soil available $\mathrm{P}$ was determined by the Bray and Kurtz P-1 method (Frank et al., 1998). Soil K, Ca, and $\mathrm{Mg}$ were determined by the neutral ammonium acetate after extraction procedure (Warncke and Brown, 1998). All other soil and compost nutrients were determined by the inductively coupled plasma (ICP) method after acid digestion (Warncke, 1998). The concentration of heavy metals in both the soil and compost were determined by microwave-assisted acid digestion (US EPA, 1995). The heavy metal concentrations added to each amended plot (Table 2) were well below those allowed by the US Environmental Protection Agency Rule 503 (US EPA, 1997).

Plots were seeded $11 \mathrm{~d}$ after compost incorporation with either: 1) Kentucky bluegrass ('Cheri', 'Baron', and 'Washington', $85 \%$ germination) at a rate of $98 \mathrm{~kg} \cdot \mathrm{ha}^{-1} ; 2$ ) perennial ryegrass ('Accent', $88 \%$ germination) at a rate of $195 \mathrm{~kg} \cdot \mathrm{ha}^{-1}$; or 3) a mixture of Kentucky bluegrass and perennial ryegrass
$(85: 15 ; \mathrm{w} / \mathrm{w})$ at a rate of $146 \mathrm{~kg} \cdot \mathrm{ha}^{-1}$. The turfgrass treatments were assigned randomly with three replicates per block. All plots received a single starter fertilizer application $\left(49,37\right.$, and $24 \mathrm{~kg} \cdot \mathrm{ha}^{-1} \mathrm{~N}, \mathrm{P}$, and $\mathrm{K}$, respectively) immediately after seeding, and were also fertilized with NPK at a rate of $49 \mathrm{~kg} \cdot \mathrm{ha}^{-1}$ in May 1999 and again in June 1999. The turf was maintained at a mowing height of $6.5 \mathrm{~cm}$ with a rotary mower (clippings removed) and irrigated as needed.

Assessment of turfgrass establishment, growth, and rust severity. Establishment was estimated as the percentage turfgrass cover and was assessed visually (on a 0 to 10 scale, where $0=$ no turf cover and $10=100 \%$ turf cover) in each plot about every 2 weeks between Aug. and Nov. 1998, and between May and Aug. 1999. Turfgrass cover was not assessed from Dec. 1998 to Apr. 1999 due to winter dormancy. Assessments were performed by one rater who evaluated the center portion of each plot from two directions and determined percentage cover based on the amount of exposed soil vs. turf. Turfgrass growth was measured from clippings collected in a $0.85-\mathrm{m}^{2}$ area from the center of each plot with a rotary mower equipped with a side adapter designed to draw the clippings into an attached paper bag. Clippings were dried for 2 $\mathrm{d}$ at $50^{\circ} \mathrm{C}$, and yield data are presented on a dry weight basis. Clipping yields were not assessed during winter dormancy and were discontinued in early July 1999 due to heatinduced stress. The severity of rust caused by naturally occurring Puccinia inoculum was assessed visually by one rater as the percentage of symptomatic turf in each plot at 6 and 9 weeks after seeding. Classification of the causal agent to the genus Puccinia was determined by microscopic examination of uredospores and by host specificity (Smiley et al., 1992). Disease severity was not rated at other times due to insufficient disease severity.

Experimental design and statistical analysis. A split-plot design with three replicates per treatment per block (three blocks) was used. Grass species served as the main plot factor and compost incorporation served as the subplot factor. Although not directly relevant to this study, the three treatment replicates per block were included in this study design to allow for the future addition of three inorganic fertilizer application treatments following turfgrass establishment as part of a long-term study. Analyses of variance were conducted with Minitab statistical software (Minitab Inc., State College, Pa.). The experiment was performed twice, designated Expts. 1 and 2, respectively, in adjacent fields using the same seed lots and compost batches.

\section{Results and Discussion}

The incorporation of composted biosolids into the nutrient-deficient subsoil used in this study significantly $(P<0.05)$ enhanced turfgrass establishment and growth. These effects were first observed and most pronounced on plots seeded with perennial ryegrass due to its shorter germination time and faster growth rate. By the 5th week after seeding in Expt. 1, all treatments showed significantly $(P<0.05)$ greater turfgrass establishment in the compost-amended compared to the nonamended plots (Table 3). Turfgrass growth as measured by clipping dry weight also was significantly $(P<0.05)$ greater for the compost-amended plots (Table 4). Similar trends in turfgrass establishment (Table 5) and growth (Table 4) were observed in Expt. 2. These compostinduced effects were apparent for the duration of the study.

The enhanced turfgrass establishment and growth observed on the compost-amended plots are most likely a result of the plantavailable nitrogen and phosphorus introduced into the seedbed with the compost (Table 1). This conclusion is supported by previous reports by Sikora et al. (1980), who attributed a similar increase in the growth of greenhousegrown fescue (Festuca arundinacea Schreb.) to the $\mathrm{N}$ supplied to the soil by composted biosolids amendment. Chen (1997) found a positive linear relationship $\left(r^{2}=0.992\right)$ between the amount of $\mathrm{N}$ supplied by a composted biosolids amendment and the yield of greenhouse-grown perennial ryegrass. Most re- 
Table 3. Establishment of turfgrass on compost-amended and nonamended subsoil in Expt. 1.

\begin{tabular}{|c|c|c|c|c|c|c|c|c|c|c|c|c|c|c|c|}
\hline \multirow[b]{3}{*}{ Treatment } & \multicolumn{15}{|c|}{ Turfgrass cover $(\%)^{\mathrm{z}}$} \\
\hline & \multicolumn{15}{|c|}{ Weeks after seeding } \\
\hline & 2 & 4 & 5 & 7 & 8 & 38 & 39 & 41 & 43 & 45 & 46 & 48 & 50 & 52 & 54 \\
\hline & \multicolumn{15}{|c|}{ Kentucky bluegrass } \\
\hline Compost $^{\mathrm{y}}$ & 3 & 18 & $33^{*}$ & $57^{*}$ & $69^{*}$ & $76^{* * * *}$ & $81^{* * * *}$ & $81^{*}$ & $85^{*}$ & 82 & $90^{* * * *}$ & 92 & $97^{* * * *}$ & $96^{* *}$ & $97^{*}$ \\
\hline No compost & 3 & 14 & 18 & 26 & 42 & 45 & 57 & 69 & 72 & 77 & 77 & 86 & 84 & 86 & 89 \\
\hline \multirow[t]{2}{*}{ SE } & 0.7 & 2.9 & 6.2 & 7.4 & 9.6 & 4.8 & 2.2 & 3.6 & 3.8 & 5.2 & 1.5 & 2.9 & 2.1 & 1.8 & 2.2 \\
\hline & \multicolumn{15}{|c|}{$K$. bluegrass/P. ryegrass mix } \\
\hline Compost & $10^{*}$ & $20^{*}$ & $41^{*}$ & $72^{* *}$ & $75 * *$ & $73^{* *}$ & $87^{*}$ & $86^{*}$ & 82 & 84 & $87^{* *}$ & 89 & $92^{* * * *}$ & $92^{* *}$ & $96^{*}$ \\
\hline No compost & 6 & 13 & 27 & 43 & 48 & 54 & 68 & 72 & 74 & 77 & 77 & 80 & 80 & 83 & 87 \\
\hline \multirow[t]{2}{*}{ SE } & 1.5 & 2.5 & 4.9 & 5.8 & 5.1 & 4.6 & 5.5 & 4.5 & 3.5 & 3.2 & 2.2 & 5.3 & 1.8 & 2.4 & 2.7 \\
\hline & \multicolumn{15}{|c|}{ Perennial ryegrass } \\
\hline Compost & 40 & $75^{* * * *}$ & $83^{* * * *}$ & $92^{* * * *}$ & $93^{* * *}$ & $77^{*}$ & $81^{*}$ & 83 & $84^{*}$ & $83^{*}$ & 86 & $88^{*}$ & $89^{*}$ & $89^{*}$ & $91^{*}$ \\
\hline No compost & 23 & 36 & 50 & 60 & 69 & 59 & 72 & 72 & 73 & 77 & 82 & 83 & 78 & 81 & 86 \\
\hline SE & 7.3 & 6.7 & 6.0 & 4.9 & 2.1 & 5.4 & 2.6 & 4.9 & 4.0 & 1.9 & 1.9 & 1.8 & 3.1 & 2.7 & 1.9 \\
\hline
\end{tabular}

${ }^{\mathrm{z}}$ Establishment was measured visually.

${ }^{y}$ Composted biosolids $\left(130 \mathrm{~m}^{3} \cdot \mathrm{ha}^{-1}\right)$ incorporated to a depth of $10-15 \mathrm{~cm}$. The compost amendment of $\mathrm{NO}_{3}-\mathrm{N}, \mathrm{P}$, and $\mathrm{K}$ supplied at 126,546 , and $182 \mathrm{~kg} \cdot$ ha ${ }^{-1}$, respectively, to each compost-amended subplot.

${ }^{*, * * * * * *}$ Significant at $\leq 0.05,0.01$, and 0.001 , respectively, by ANOVA.

Table 4. Growth of turfgrass seeded on compost-amended and nonamended subsoil.

\begin{tabular}{|c|c|c|c|c|c|c|c|c|c|c|}
\hline \multirow[b]{4}{*}{ Treatment } & \multicolumn{10}{|c|}{ Dry wt of clippings $\left(\mathrm{g} \cdot \mathrm{m}^{-2}\right)$} \\
\hline & \multicolumn{10}{|c|}{ Weeks after seeding ${ }^{z}$} \\
\hline & \multicolumn{5}{|c|}{ Expt. 1} & \multicolumn{5}{|c|}{ Expt. 2} \\
\hline & 6 & 14 & 39 & 42 & 45 & 6 & 14 & 39 & 42 & 45 \\
\hline & \multicolumn{10}{|c|}{ Kentucky bluegrass } \\
\hline Compost $^{\mathrm{y}}$ & 1.4 & 4.4 & $15.3^{* *}$ & $14.8^{* *}$ & $4.4^{*}$ & 0.6 & $6.4^{* *}$ & $31.6^{* * *}$ & $25.0^{* *}$ & $7.6^{*}$ \\
\hline No compost & 1.0 & 0.7 & 3.1 & 4.3 & 1.7 & 0.6 & 0.3 & 4.4 & 6.0 & 2.1 \\
\hline \multirow[t]{2}{*}{ SE } & 0.3 & 2.1 & 2.3 & 2.1 & 1.0 & 0.1 & 1.4 & 2.9 & 3.6 & 1.9 \\
\hline & \multicolumn{10}{|c|}{$K$. bluegrass/P. ryegrass mix } \\
\hline Compost & 2.1 & $10.1^{*}$ & $17.6^{*}$ & $16.1^{\text {** }}$ & $3.3^{* *}$ & $1.6^{*}$ & $6.0^{*}$ & $18.4^{*}$ & 17.1 & 3.4 \\
\hline No compost & 1.1 & 0.7 & 6.7 & 8.4 & 2.6 & 0.3 & 1.4 & 12.4 & 13.3 & 3.0 \\
\hline \multirow[t]{2}{*}{ SE } & 0.8 & 2.8 & 4.4 & 1.5 & 0.1 & 0.5 & 1.2 & 2.5 & 2.8 & 0.3 \\
\hline & \multicolumn{10}{|c|}{ Perennial ryegrass } \\
\hline Compost & $16.9^{*}$ & $8.8^{* *}$ & 9.2 & 11.5 & 2.0 & $11.4^{*}$ & $8.2^{*}$ & $15.8^{* *}$ & $17.3^{* * *}$ & $3.8^{*}$ \\
\hline No compost & 2.1 & 0.7 & 6.3 & 8.8 & 1.9 & 2.3 & 0.9 & 8.9 & 8.6 & 1.8 \\
\hline SE & 4.1 & 1.9 & 2.4 & 3.1 & 0.5 & 3.6 & 1.6 & 1.7 & 1.5 & 0.7 \\
\hline
\end{tabular}

${ }^{\mathrm{z}}$ Growth was measured by collecting clippings from each plot with a rotary mower followed by drying at 50 ${ }^{\circ} \mathrm{C}$ for $2 \mathrm{~d}$.

${ }^{y}$ Composted biosolids $\left(130 \mathrm{~m}^{3} \cdot \mathrm{ha}^{-1}\right)$ incorporated to a depth of $10-15 \mathrm{~cm}$. The compost amendment of $\mathrm{NO}_{3}-\mathrm{N}$, $\mathrm{P}$, and $\mathrm{K}$ supplied at 126,546 , and $182 \mathrm{~kg} \cdot \mathrm{ha}^{-1}$, respectively, to each compost-amended subplot.

${ }^{*}, * *, * * *$ Significant at $\leq 0.05,0.01$, and 0.001 , respectively, by ANOVA.

Table 5. Establishment of turfgrass on compost-amended and nonamended subsoil in Expt. 2.

\begin{tabular}{|c|c|c|c|c|c|c|c|c|c|c|c|c|c|c|c|}
\hline \multirow[b]{3}{*}{ Treatment } & \multicolumn{15}{|c|}{ Turfgrass cover $(\%)^{\mathrm{z}}$} \\
\hline & \multicolumn{15}{|c|}{ Weeks after seeding } \\
\hline & 2 & 4 & 5 & 7 & 8 & 38 & 39 & 41 & 43 & 45 & 46 & 48 & 50 & 52 & 54 \\
\hline & \multicolumn{15}{|c|}{ Kentucky bluegrass } \\
\hline Compost $^{\mathrm{y}}$ & 3 & 14 & 22 & 44 & $65^{*}$ & $74^{* *}$ & $83^{*}$ & 84 & $87^{*}$ & $89^{*}$ & $91^{*}$ & 94 & 96 & 99 & $99^{*}$ \\
\hline No compost & 3 & 10 & 15 & 29 & 43 & 49 & 68 & 67 & 72 & 77 & 82 & 87 & 92 & 92 & 96 \\
\hline \multirow[t]{2}{*}{ SE } & 1.3 & 4.2 & 5.3 & 6.3 & 7.4 & 5.1 & 5.7 & 7.0 & 6.0 & 4.4 & 3.7 & 3.3 & 3.3 & 3.0 & 1.4 \\
\hline & \multicolumn{15}{|c|}{$K$. bluegrass $/ P$. ryegrass mix } \\
\hline Compost & 9 & 23 & 33 & 53 & $72^{*}$ & $80^{*}$ & 81 & $83^{*}$ & 84 & 87 & $88^{*}$ & $92^{*}$ & $96^{*}$ & 96 & 97 \\
\hline No compost & 7 & 21 & 27 & 38 & 46 & 62 & 76 & 73 & 76 & 77 & 80 & 83 & 88 & 89 & 95 \\
\hline \multirow[t]{2}{*}{ SE } & 1.9 & 3.7 & 5.7 & 7.2 & 7.8 & 6.3 & 3.6 & 3.5 & 3.4 & 4.1 & 3.1 & 3.6 & 3.1 & 2.8 & 1.5 \\
\hline & \multicolumn{15}{|c|}{ Perennial ryegrass } \\
\hline Compost & 29 & $59^{*}$ & $69^{* *}$ & $80^{*}$ & $91^{* * * *}$ & $89^{* *}$ & $84^{* * *}$ & $88^{* * * *}$ & $86^{* * *}$ & $84^{* *}$ & 87 & $92^{*}$ & 93 & $96^{*}$ & $97^{* *}$ \\
\hline No compost & 25 & 43 & 49 & 64 & 72 & 71 & 75 & 79 & 78 & 76 & 79 & 86 & 88 & 87 & 91 \\
\hline SE & 8.1 & 4.9 & 5.0 & 5.5 & 3.2 & 4.3 & 1.7 & 1.2 & 1.2 & 1.7 & 3.0 & 1.8 & 3.1 & 2.5 & 1.2 \\
\hline
\end{tabular}


cently, Markham (1998) attributed enhanced establishment of creeping bentgrass on a composted biosolids-amended putting green rootzone mix to the $\mathrm{N}$ and $\mathrm{P}$ introduced by the incorporation of the composted biosolids to the rootzone mix.

The year-long enhancement of turf establishment and growth observed in this study is also consistent with previous reports in other cropping systems of prolonged effects of nutrients introduced into soil through the incorporation of composted biosolids. For example, O'Keefe et al. (1986) reported an extended availability of N to maize (Zea mays L.) planted in soil with incorporated composted biosolids, with a rapid rate of $\mathrm{N}$ mineralization for the first 28 weeks and a slow but sustained rate for the next 45 weeks. Darmody et al. (1983) reported high residual levels of $\mathrm{Ca}, \mathrm{P}$, and $\mathrm{K} 3$ years after incorporation of composted biosolids into soil. They also reported a decrease in bulk density and an increase in the moisture-holding capacity 4 years after composted biosolids were incorporated into a silt loam. It is highly likely that similar changes, although not measured, took place in the heavy clay subsoil used in this study.

The severity of leaf rust was significantly $(P<0.05)$ lower on perennial ryegrass seeded on the compost-amended plots at 6 weeks after seeding in Expt. 1 and for up to 9 weeks after seeding in Expt. 2 (Table 6). Although it has been reported that applications of compost topdressing can suppress foliar turf diseases and that the incorporation of compost into soil can suppress soil-borne diseases, this is the first report of a foliar turf disease being suppressed by the incorporation of compost into soil. Since it is well-documented that the development of rust in turfgrass is greatly reduced by increased $\mathrm{N}$ fertility (Smiley et al., 1992), the lower rust severity observed in the compost-amended ryegrass plots was most likely due to an increase in plant-available $\mathrm{N}$ supplied by the compost (Table 1). Garling (2000) attributed suppression of dollar spot on creeping bentgrass to the plant-available $\mathrm{N}$ provided by composted biosolids and yardwastes topdressings. Although increased growth rates and removal of symptomatic turf via mowing are usually cited as the mechanisms of how increased $\mathrm{N}$ fertility results in decreased disease, the exact mechanism(s) have yet to be documented experimentally. Given the spatial separation between the location of the compost and the site of pathogen activity, however, it is possible that the suppression of rust observed in this study was due to the induction of systemic resistance by microorganisms present in the compost. Zhang et al. (1996) demonstrated compost-induced systemic acquired resistance in cucumber to Pythium root rot and anthracnose. Most recently, Enebak and Carey (2000) showed that such a mechanism was responsible for resistance to fusiform rust (Cronartium quercuum f. sp. fusiforme Burds. et Snow) of loblolly pine (Pinus taeda L.) seedlings treated with plant growth promoting rhizobacteria(PGPR).

These results clearly demonstrate that composted biosolids can be used to enhance

Table 6. Severity of rust (Puccinia sp.) on turfgrass seeded on compostamended and nonamended subsoil.

\begin{tabular}{|c|c|c|c|c|}
\hline \multirow[b]{4}{*}{ Treatment } & \multicolumn{4}{|c|}{ Rust severity $(\%)^{\mathrm{z}}$} \\
\hline & \multicolumn{4}{|c|}{ Weeks after seeding } \\
\hline & \multicolumn{2}{|c|}{ Expt. 1} & \multicolumn{2}{|c|}{ Expt.2 } \\
\hline & 6 & 9 & 6 & 9 \\
\hline & \multicolumn{4}{|c|}{ Kentucky bluegrass } \\
\hline Compost $^{y}$ & 7 & 8 & 6 & 6 \\
\hline No compost & 10 & 5 & 8 & 8 \\
\hline \multirow[t]{2}{*}{$\mathrm{SE}$} & 2.2 & 2.5 & 1.2 & 2.3 \\
\hline & \multicolumn{4}{|c|}{$K$. bluegrass $/ P$. ryegrass mix } \\
\hline Compost & 9 & 14 & 10 & 19 \\
\hline No compost & 12 & 15 & 12 & 23 \\
\hline \multirow[t]{2}{*}{$\mathrm{SE}$} & 2.1 & 4.0 & 2.1 & 5.5 \\
\hline & \multicolumn{4}{|c|}{ Perennial ryegrass } \\
\hline Compost & $27^{* *}$ & 38 & $37^{* *}$ & $49^{*}$ \\
\hline No compost & 52 & 46 & 60 & 71 \\
\hline SE & 6.1 & 6.0 & 5.1 & 8.1 \\
\hline
\end{tabular}

the establishment and growth of turfgrass on disturbed urban soils. This is of particular benefit for the installation of new lawns on nutrient-deficient, structureless urban soils where erosion is likely when turf is slow to establish. These results also present the first evidence of a foliar turf disease being suppressed by the incorporation of composted biosolids into the soil profile. Future research focusing on the mechanisms of compost-induced improvements of turf will help in the development of practical guidelines for the use of composted urban wastes to improve the quality of urban soils and the establishment, growth, and overall vigor of turf.

\section{Literature Cited}

Aggelides, S.M. and P.A. Londra. 1999. Effects of compost produced from town wastes and sewage sludge on the physical properties of a loamy and a clay soil. Bioresour. Technol. 71:253259.

Barron, L. 1923. Lawn making, together with the proper keeping of putting greens. Doubleday, Garden City, N.Y.

Boulter, J.I., G.J. Boland, and J.T. Trevors. 1999. Evaluation of compost for biological control of dollar spot (Sclerotinia homoeocarpa) on creeping bentgrass (Agrostis palustris). Phytopathology 89:S8.

Chen, L. 1997. Nitrogen and iron nutrition of plants as induced by composts and compost microorganisms. PhD Diss., The Ohio State Univ.

Craft, C.M. and E.B. Nelson. 1996. Microbial properties of composts that suppress damping off and root rot of creeping bentgrass caused by Pythium graminicola. Appl. Environ. Microbiol. 62:1550-1557.

Cunniff, P. 1995. (ed.). Official methods of analysis of the Association of Official Analytical Chemists International. 16th ed. AOAC Intl., Gaithersburg, Md.

Darmody, R.G., J.E. Foss, and M. McIntosh. 1983. Municipal sewage sludge compost-amended soils: Some spatiotemporal treatment effects. J. Environ. Qual. 12: 231-6.

Eguiza, J.E., J.L. Eggens, and K. Carey. 1991 Composted sewage sludge as a nitrogen source for the maintenance of putting green and fairway type turf. Guelph Turfgrass Institute Annual Research Report 1991. (Available online at http:/ /www.uoguelph.ca/GTI/91 anrep/91r2.htm) (verified 19 Dec. 2000).

Enebak, S.A. and W.A. Carey. 2000. Evidence for induced systemic protection to fusiform rust in loblolly pine by plant-growth promoting rhizobacteria. Plant Dis. 84:306-308.

Finstein, M.S., F.C. Miller, P.F. Strom, S.T. Macgregor, and K.M. Psarianos. 1983. Composting ecosystem management for waste treatment. Biotechnology (4):347-353.

Frank, K., D. Beegle, and J. Denning. 1998 (Revised). Phosphorus, p. 21-29. In J.R. Brown (ed.). Recommended chemical soil test procedures for the north central region. Missouri Agr. Expt. Sta. Columbia. (Available online at: http:/ /muextension.missouri.edu/xplorpdf/miscpubs/ sb1001.pdf) (verified 19 Dec. 2000).

Garling, D.C. 2000. The effects of compost topdressing on turf quality, foliar nitrogen concentration and dollar spot severity on creeping bentgrass/annual bluegrass golf course fairways. MS Thesis, The Ohio State Univ., Columbus.

Garling, D.C. and M.J. Boehm. 2001. Temporal effects of compost topdressings and inorganic fertilizer applications on nitrogen fertility of fairway height creeping bentgrass and annual bluegrass. Agron. J. 93:548-555.

Gelderman, R.H. and D. Beegle. 1998. NitrateNitrogen. p. 17-20. In J.R. Brown (ed.). Recommended chemical soil test procedures for the north central region. Missouri Agr. Expt. Sta., Columbia. (Available online at: http:// muextension.missouri.edu/xplorpdf/miscpubs/ sb1001.pdf) (verified 19 Dec. 2000).

Hoitink, H.A.J. and M.J. Boehm. 1999. Biocontrol within the context of soil microbial communities: A substrate-dependent phenomenon. Annu. Rev. Phytopathology 37:427-446.

Hornick, S.B. and J.F. Parr. 1987. Restoring the productivity of marginal soils with organic amendments. Amer. J. Altern. Agr. 2:64-68.

Kuter, G.A., H.A.J. Hoitink, and L.A. Rossman. 1985. Effects of aeration and temperature on composting of municipal sludge in a full-scale vessel system. J. Water Pollut. Control Fed. 57(4):309-315.

Larney, F.J. and H.H. Janzen. 1996. Restoration of productivity to a desurfaced soil with livestock manure, crop residue, and fertilizer amendments. Agron. J. 88:921-927. 
Logsden, G. 1991. Compost use in sod production. Biocycle 32(3):64-65.

Lumsden, R.D., J.A. Lewis, and P.D. Millner. 1983. Effect of composted sewage sludge on several soilborne pathogens and diseases. Phytopathology 73:1543-1548.

Markham, T.D. 1998. Use of composts in sandbased putting greens and their impact on turf establishment and health. MS thesis, The Ohio State Univ., Columbus.

Murray, J.J. 1982. Use of composted sewage sludge for turfgrass. Misc. Pub. USDA, July 1982 (1422):281-284.

Nelson, E.B. and C.M. Craft. 1991a. Suppression of brown patch with top-dressings amended with composts and organic fertilizers. Biol. Cult. Tests Control Plant Dis. 6:90.

Nelson, E.B. and C.M. Craft. 1991b. Suppression of red thread with top-dressings amended with composts and organic fertilizers. Biol. Cult. Tests Control Plant Dis. 6:101.

Nelson, E.B. and C.M. Craft. 1992a. Suppression of dollar spot on creeping bentgrass and annual bluegrass turf with compost-amended topdressings. Plant Dis. 76:954-0958.

Nelson, E.B. and C.M. Craft. 1992b. Suppression of Typhula blight with top-dressings amended with composts and organic fertilizers. Biol. Cult. Tests Control Plant Dis. 6:90, 1991.

O'Keefe, B.E., J. Axley, and J.J. Meisinger. 1986. Evaluation of nitrogen availability indexes for a sludge compost amended soil. J. Environ. Qual. 15:121-128.

Pascual, J.A., M. Ayuso, C. García, and T. Hernandez. 1997. Characterization of urban wastes according to fertility and phytotoxicity parameters. Waste Mgt. Res. 15:103-112.

Pound, W. and J. Street. 1991. Lawn establishment, Ext. Bul. 546. The Ohio State Univ. (Available online at http://www.ag.ohio-state.edu/ ohioline/b546/index.html) (verified 19 Dec. 2000).

Serra-Wittling, C., S. Houot, and C. Alabouvette. 1996. Increased soil suppressiveness to Fusarium wilt of flax after addition of municipal solid waste compost. Soil Biol. Biochem. 28:12071214.

Sikora, L.J., C.F. Tester, J.M. Taylor, and J.F. Parr. 1980. Fescue yield response to sewage sludge compost amendments. Agron. J. 72:79-84.

Sikora, L.J. and V. Yakovchenko. 1996. Soil organic matter mineralization after compost amendment. Soil Sci. Soc. Amer. J. 60:14011404.

Smiley, R.W., P.H. Dernoeden, and B.B. Clarke. 1992. Compendium of turfgrass diseases. Amer. Phytopathol. Soc. Press, St. Paul, Minn.

Thurn, M.C. 1993. Organic source effects on disease suppression and physical stability of putting green rootzone mixes. MS Thesis, Cornell Univ., Ithaca, N.Y.

U.S. Environmental Protection Agency. 1995. Mi- crowave assisted acid digestion. SW-846 Online test methods for evaluating solid waste physical/chemical methods. U.S. Environ. Protection Agency, Office of Solid Waste [Online]. Available at http://www.epa.gov/epaoswer/ hazwaste/test/main.htm (verified 19Dec. 2000).

U.S. Environmental Protection Agency. 1997. Sec. 503.13 Pollutant limits, p. 693-694. In: Code of Federal Regulations, Title 40-Protection of the Environment, Chapter 1, Part 503, Subpart BLand Application. [40CFR503.13]. (Available online at http://www.epa.gov/reg5oh2o/ npdestek/npdprtg6.htm) (verified 19Dec. 2000).

Warncke, D. 1998. Greenhouse root media, p. 6164. In: J.R. Brown (ed.). Recommended chemical soil test procedures for the north central region. Missouri Agr. Expt. Sta., Columbia. (Available online at: http:// muextension.missouri.edu/xplorpdf/miscpubs/ sb1001.pdf) (verified 19 Dec. 2000).

Warncke, D. and J.R. Brown. 1998. Potassium and other basic cations, p. 31-33. In: J.R. Brown (ed.). Recommended chemical soil test procedures for the north central region. Missouri Agr. Expt. Sta., Columbia. (Available online at: http:/ /muextension.missouri.edu/xplorpdf/miscpubs/ sb1001.pdf) (verified 19 Dec. 2000).

Zhang, W., W.A. Dick, and H.A.J. Hoitink. 1996. Compost-induced systemic acquired resistance in cucumber to Pythium root rot and anthracnose. Phytopathology 86:1066-1070. 